\title{
Isolation and Identification of Bacteria in Retailed Smoked Fish, Within Bauchi Metropolis
}

\author{
Moshood A. Yusuf ${ }^{1}$, TengkuHaziyamin Abdul Tengku Abdul Hamid ${ }^{2}$ \\ ${ }^{1,2}$ Department of Biotechnology, Kulliyyah of Science, International Islamic University Malaysia, Bandar \\ InderaMahkota, Jalan Istana, 25200 Kuantan, Malaysia.
}

\begin{abstract}
Bauchi metropolis, from three different locations, for the isolation and identification of bacteria. 16 (53\%) of the samples were catfish (Clarias specie) which were dried in the sun before smoking (DSF) and the other 14 (47\%) samples were frozen mackerel which had been thawed before smoking (ISF). The dried smoked fish (DSF) samples showed the mean bacteria count of $2.4 \times 10^{4} \mathrm{cfu} g$ which was observed to be less than the mean count in iced smoked fish (ISF) samples which is $2.8 \times 10^{4} \mathrm{cfu} / \mathrm{g}$. The three different locations which includes: Yelwa market, Wunti market and Muda Lawan market showed different aerobic bacteria count. A serial dilution of up to $10^{-3}$ in peptone water was carried out. $1 \mathrm{ml}$ of each sample was cultured by pour plating on Nutrient agar and McConkey agar and incubated at $37^{\circ} \mathrm{C}$ for 24 hours. The isolates identified were Staphylococcus aureus, Salmonella typhi, Proteus mirabilis, Klebsiella spp, Streptococcus spp and Bacillus cereus. The biochemical tests carried out for the identification for these isolates includes: Catalase test, Coagulase test, Urease test, triple sugar ion test, citrate utilization test and indole formation test.
\end{abstract}

Key Word: smoked fish, bacteria, identification, serial dilution

\section{Introduction}

Fish are aquatic vertebrate animals that are typically ectothermic (Previously cold blooded), covered with scales, and equipped with two sets of paired fins and several unpaired fins. Over half of all vertebrates are fishes. Fish are of tremendous importance as food for people around the world, either collected from the wild or farmed in much the same way as cattle or chickens. Fish are cooked and eaten fresh or more often, dried in the sun after removal of their guts and scales and some times they are smoked.

Preservation of fish by smoking is carried out after catching and may be eaten without further cooking. From the processing centers to the market centers, smoked fishes are often contaminated with bacteria among other microorganisms. Also during handling of fish, the natural flora of the environment will be contaminated with organisms associated with man, such as members of Enterobacteriaceae and Staphylococcus which can grow well at $30-37^{\circ} \mathrm{C}(1)$.

The rapid increase in the quantity of fish caught was caused by the increasing world demand for protein, as human population expanded rapidly in the 1950s and 1960s there was an urgent need for more dietary protein at low cost. Research has shown that, fish smoking is the most widely practiced and recommended method of preservation where sophisticated equipment for more improved methods are lacking. Smoking of food is achieved by lowering of the water activity via application of gentle heat. The surface of food which will normally support most commensal organisms, is dried while the heat and chemicals inherent in the smoke deprives microbes of necessary growth factors [2].

Smoking is one of the oldest methods of preserving fish, or any other meats for that matter. Long before there were refrigerators and freezers our fishing ancestors learned to use a combination of salt and smoke to keep fish from spoiling. Today smoking is no longer "necessary", but it remains popular for the flavor it gives to such fish as salmon, tuna, trout etc.

Bacterial contamination in food often results in food spoilage as well as life-threatening health hazards like food poisoning [3]. Prevention thus helps in the preservation of food quality and public health enhancement.

These facts greatly influenced the interest of this study which aimed at assessing the bacterial load of retailed smoked fish.

\section{Materials And Methods}

\section{SAMPLE COLLECTION}

A total of 30 samples of smoked fish were collected from Bauchi metropolis the areas of collection were Yelwa market, Wunti market and Muda Lawan market. The smoked fish samples were frozen mackerel which had been thawed and then smoked without drying and catfish Clarias specie (Tarwada in Hausa) which 
were dried in the sun before smoking. The samples were collected in sterile containers and labeled with date and place of collection. All fish samples were collected directly from retailers.

\subsection{PREPARATION OF SAMPLES}

Each sample was pounded in a steriled porcelain mortar [2]. 1gram of each sample was aseptically introduced into $9 \mathrm{ml}$ of peptone water in a universal bottle, to give $10^{-1}$ dilution and three subsequent serial dilutions were prepared in test tubes by transferring $1 \mathrm{ml}$ to $9 \mathrm{ml}$ of peptone water. [4].

\subsection{BACTERIAL ANALYSIS OF SAMPLE}

$1 \mathrm{ml}$ dilution of each sample was plated on MacConkey agar and Nutrient agar. Replicate plates for each preparation were incubated aerobically at $37^{\circ} \mathrm{C}$ for 24 hours. Colonies that grew on the plates after 24 hours of incubation were counted using colony counter. The samples were plated using pour plating method. [2].

\subsection{IDENTIFICATION OF ISOLATES}

The bacterial isolates were identified and classified using a combination of the methods as recommended by(3), (5) and(6).

Distinct colonies developing on the culture plates were observed for their pigmentation, margin, elevation and opacity.

Gram's staining was done using 24 hours pure culture. The stained slides were then examined under the microscope with oil immersion objective lens (x100). The Gram's reaction, shape, arrangement and size of the cells were examined. Biochemical characteristics of the isolates were determined by employing the following tests on a fresh culture; Catalase test, Coagulase test, Citrate utilization test, Urease test, Indole formation test, motility test and Triple sugar ion test. [6] and [7].

\section{Results}

A total of 30 smoked fish samples from Yelwa market, Muda Lawan market and Wunti market were screened for bacterial contamination.

Results were compiled separately for the 16 dried smoked fish samples and 14 iced smoked fish samples.

Table 1. Shows the bacterial plate count per gram of dried smoked fish and iced smoked fish samples. The mean count of dried smoked fish was observed to be $2.4 \times 10^{4} \mathrm{cfu} / \mathrm{g}$ and that of iced smoked fish was found to be $2.8 \mathrm{x}$ $10^{4} \mathrm{cfu} / \mathrm{g}$.

Table 2. Shows the mean bacteria count obtained from the three different sources of smoked fish samples. The smoked fish samples obtained from Yelwa market showed the highest bacterial contamination of iced and dried smoked fish samples with mean bacteria count of $3.3 \times 10^{4} \mathrm{cfu} / \mathrm{g}$ and $3.2 \times 10^{4}$ respectively. The least of bacteria contamination was obtained from Wunti market, from the dried smoked fish samples with the mean value of $1.8 \times 10^{4} \mathrm{cfu} / \mathrm{g}$.

TABLE 1. Bacteria Plate Count Per Gram Of 16 Dried Smoked Fish (Dsf) Samples And 14 Iced Smoked Fish (Isf) Samples.

\begin{tabular}{|l|l|l|}
\hline S/No & \multicolumn{1}{|c|}{ DSF } & ISF \\
\hline 1 & $9.3 \times 10^{3}$ & $2.6 \times 10^{4}$ \\
\hline 2 & $1.1 \times 10^{4}$ & $2.2 \times 10^{4}$ \\
\hline 3 & $2.2 \times 10^{4}$ & $2.4 \times 10^{4}$ \\
\hline 4 & $2.2 \times 10^{4}$ & $4.3 \times 10^{4}$ \\
\hline 5 & $1.9 \times 10^{4}$ & $2.1 \times 10^{4}$ \\
\hline 6 & $2.6 \times 10^{4}$ & $2.6 \times 10^{4}$ \\
\hline 7 & $1.7 \times 10^{4}$ & $2.4 \times 10^{4}$ \\
\hline 8 & $1.4 \times 10^{4}$ & $3.1 \times 10^{4}$ \\
\hline 9 & $2.1 \times 10^{4}$ & $2.9 \times 10^{4}$ \\
\hline 10 & $2.4 \times 10^{4}$ & $4.6 \times 10^{4}$ \\
\hline 11 & $1.3 \times 10^{4}$ & $2.1 \times 10^{4}$ \\
\hline 12 & $2.2 \times 10^{4}$ & $2.2 \times 10^{4}$ \\
\hline 13 & $1.8 \times 10^{4}$ & $3.9 \times 10^{4}$ \\
\hline 14 & $1.9 \times 10^{4}$ & $2.3 \times 10^{4}$ \\
\hline 15 & $2.1 \times 10^{4}$ & \\
\hline 16 & $2.0 \times 10^{4}$ & \\
\hline MEAN & \\
$2.8 \times 10^{4}$ & \\
\hline
\end{tabular}

KEY: DSF, dried smoked fish.

ISF, iced smoked fish. 
Isolation And Identification Of Bacteria In Retailed Smoked Fish, Within Bauchi Metropolis Muda Lawan market has the least bacteria count for the iced smoked fish samples with the mean value of $2.6 \mathrm{x}$ $10^{4} \mathrm{cfu}$

Table 2. Mean Bacteria Count For The Three Different Sources Of Smoked Fish Samples.

\begin{tabular}{|l|l|l|l|l|l|}
\hline S/No & $\begin{array}{l}\text { Sample } \\
\text { source }\end{array}$ & \multicolumn{2}{|l|}{ Iced smoked fish samples } & \multicolumn{2}{l|}{ Dried smoked fish samples } \\
\hline & $\begin{array}{l}\text { Total Number of } \\
\text { samples }\end{array}$ & $\begin{array}{l}\text { Mean count } \\
\text { values(cfu/g) }\end{array}$ & $\begin{array}{l}\text { Total Number of } \\
\text { samples }\end{array}$ & $\begin{array}{l}\text { Mean } \\
\text { value(cfu/g) }\end{array}$ \\
\hline 1. & $\begin{array}{l}\text { Yelwa } \\
\text { market }\end{array}$ & 5 & $3.3 \times 10^{4}$ & 6 & $3.2 \times 10^{4}$ \\
\hline 2 & $\begin{array}{l}\text { Wunti } \\
\text { market }\end{array}$ & 5 & $3.1 \times 10^{4}$ & 5 & $1.8 \times 10^{4}$ \\
\hline 3 & $\begin{array}{l}\text { Muda } \\
\text { Lawan } \\
\text { market }\end{array}$ & 4 & $2.6 \times 10^{4}$ & 5 & $2.0 \times 10^{4}$ \\
\hline
\end{tabular}

Figures 1 and 2 shows the percentage of occurrence of the different bacteria types identified in the total smoked fish samples of both iced and dried smoked fish samples. Bacillus cereus shows the highest percentage occurrence in iced smoked fish and Staphylococcus aureus had the highest occurrence in dried smoked fish. Bacillus cereus in the iced smoked fish having a percentage of 57\% and Staphylococcus aureus having a percentage of $44 \%$ in the dried smoked fish samples. The least in percentage occurrence in the iced smoked fish were Klebsiella spp and Streptococcus spp, each having 7\% occurrence. And in dried smoked fish, Proteus and Klebsiella spp were observed to have the least percentage occurrence.

Table 3: Shows Isolates In 16 Dried Smoked Fish Samples With Their Number Of Occurrence And Percentage Of Occurrence.

\begin{tabular}{|l|l|l|}
\hline Isolates & Number of occurrence & Percentage of occurrence \\
\hline Staphylococcus aureus & 7 & $44 \%$ \\
\hline Bacillus specie & 5 & $31 \%$ \\
\hline Proteus mirabilis & 1 & $6 \%$ \\
\hline Klebsiella specie & 1 & $6 \%$ \\
\hline Salmonella typhi & 2 & $13 \%$ \\
\hline
\end{tabular}

Table 3 and 4 shows the number of occurrence and percentage of occurrence of the isolates in dried smoked fish, with 16 total samples and iced smoked fish with 14 total samples respectively. And a bar chart is plotted, with frequency against isolates. See figure 1 and 2.

Table 4: Shows Isolates In 14 Iced Smoked Fish Samples With Their Number Of Occurrence And Percentage Of Occurrence.

\begin{tabular}{|l|l|l|}
\hline Isolates & Numberof occurrence & Percentage of occurrence \\
\hline Bacillus cereus & 8 & $57 \%$ \\
\hline Staphylococcus aureus & 4 & $29 \%$ \\
\hline Klebsiella specie & 1 & $7 \%$ \\
\hline Streptococcus specie & 1 & $7 \%$ \\
\hline
\end{tabular}

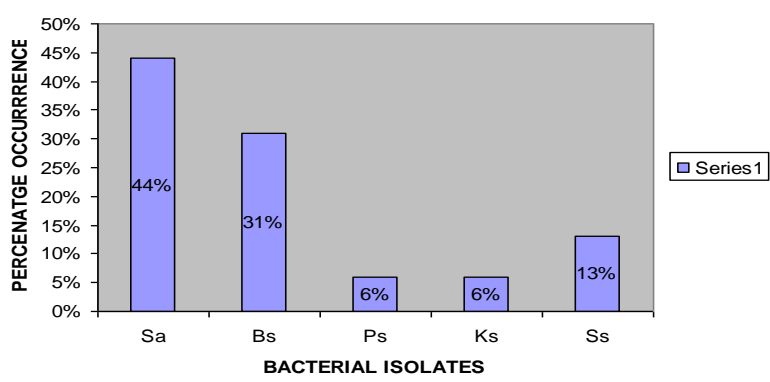

Figure 1: Bar chart showing percentage occurrence of Bacterial isolates in dried smoked fish.

Key:

$\mathrm{Sa}=$ Staphylococcus aureus

$\mathrm{Bs}=$ Bacillus cereus

$\mathrm{Ps}=$ Proteus mirabilis

$\mathrm{Ks}=$ Klebsiella specie 


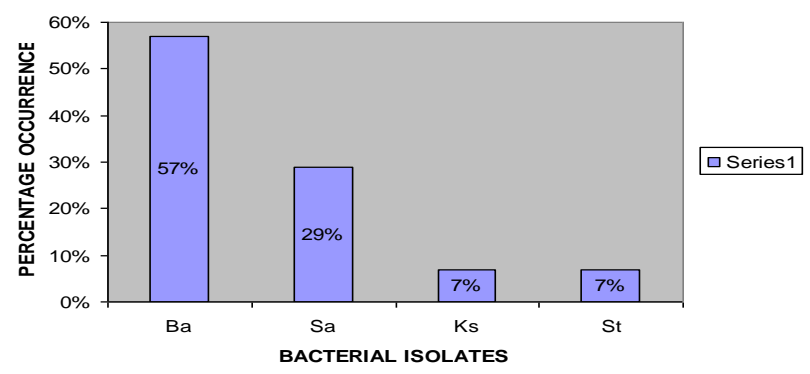

Figure 2: Bar chart showing percentage occurrence of Bacterial isolates in iced smoked fish.

Key:

$\mathrm{Ba}=$ Bacillus cereus

$\mathrm{Sa}=$ Staphylococcus aureus

Ks $=$ Klebsiella specie

$\mathrm{St}=$ Streptococcus specie

\section{Discussion Of Results}

From the total samples of smoked fish examined, all showed positive results for bacterial isolates. These results agree with the report of [9] and [2] that bacteria are contaminants of smoked fish.

Six different types of bacteria were isolated, which includes:

Bacillus cereus, Staphylococcus aureus, Proteus mirabilis, Klebsiella spp, Salmonellae typhi and Streptococcus spp. These organisms may have contaminated the smoked fish through human handlers, air and soil. The presence of these organisms in the smoked fish samples might be due to increase in moisture content of the product during storage and also increase in temperature which favors the growth of these organisms. During handling of fish the natural flora of the fish environment will be contaminated with organisms associated with man, such as members of the Enterobacteriacea and Staphylococcus aureus which can grow well at 30$37^{\circ} \mathrm{C}(2)$.

The study revealed a mean value of $2.4 \times 10^{4} \mathrm{cfu} / \mathrm{g}$ of dried smoked fish (DSF) and $2.8 \times 10^{4} \mathrm{cfu} / \mathrm{g}$ of iced smoked fish (ISF), which is higher than the mean for DSF samples, see table 1.The bacteria count for DSF ranged from $9.3 \times 10^{3}-2.6 \times 10^{4} \mathrm{cfu} / \mathrm{g}$ which is less than the range for ISF samples, which ranged from $2.1 \times 10^{4}$ $-4.6 \times 10^{4} \mathrm{cfu} / \mathrm{g}$. The mean and range of ISF samples are higher than those of DSF sample. This could be due to the higher level of moisture content of the ISF samples, which is favorable to the bacteria. Bacteria proliferate readily within a water activity level of 0.80 and 0.85 , [9]. This is an important criterion for bacteria specie to flourish well in a substrate. ISF has higher moisture content than the DSF. The difference in water activity is due to the variation in smoking time of the products. The DSF is subjected to longer smoking time than the ISF.

The difference in the mean bacteria counts of samples obtained from the three different markets, showed that the quality standards of the product varies, see table 2 . This could be due to the differences in the method of processing, storage, distribution and handling of the smoked fish samples. Samples obtained from Yelwa market had the highest degree of bacterial contamination in both ISF samples and DSF samples, with the mean count of $3.3 \times 10^{4} \mathrm{cfu} / \mathrm{g}$ and $3.2 \times 10^{4} \mathrm{cfu} / \mathrm{g}$ respectively. This was followed by the samples obtained from Wunti market for ISF samples with the mean value of $3.1 \times 10^{4} \mathrm{cfu} / \mathrm{g}$, then followed by Muda Lawan market with the mean value of $2.6 \times 10^{4} \mathrm{cfu} / \mathrm{g}$ for ISF samples. Dried smoked fish obtained from Wunti market has the least bacterial contamination level, with the mean count of $1.8 \times 10^{4} \mathrm{cfu} / \mathrm{g}$.

Bacillus cereus was found to have the highest frequency of occurrence in iced smoked fish samples, with $57 \%$ occurrence, when compared with the other isolates. Staphylococcus aureus had the highest frequency of occurrence in the dried smoked fish samples (DSF), with the value of $44 \%$. In the dried smoked fish samples, Bacillus cereus had $31 \%$ occurrence, Salmonella typhi had 13\%, Klebsiella spp and Proteus mirabilis both had $6 \%$ occurrence each. In the iced smoked fish samples, Staphylococcus aureus had 29\% occurrence, Klebsiella spp and streptococcus spp both had 7\% occurrence each. These counts can generally be regarded as acceptable limits. However, they are considered as potentially hazardous as food with these levels $\left(10^{4} \mathrm{cfu} / \mathrm{g}\right)$ of contamination may result in food-borne illness if consumed.

The prevalence of Staphylococcus aureus is of public health significance because it has been incriminated with food-borne intoxication and infection. Its ability to produce enzymes and toxins is responsible for this effect. [9]. The organism must have contaminated the smoked fish through human handlers. Its survival may be related to its ability to survive high salt level. It can grow well at temperature of $30-37^{\circ} \mathrm{C}$. [2]. The presence of Bacillus and Salmonella species are also important, because they may result in food borne illnesses. The presence of Salmonella spp indicates poor food preparation and handling practices such as cross contamination. 
Most of the isolated organisms are probably contaminants after the smoking operation, and they are mostly spoilage organisms. However, potentially pathogenic organisms isolated from smoked fish showed the need for proper hygienic conditions for processing and distribution of products.

As reported by [2], that selling of smoked fish on wooden or metal tables on open quay-sides increases the several potential bacteriological dangers, and the more or less lengthy exposure to increasing temperature that permits spoilage bacteria to multiply.

\section{References}

[1] Adams M.R and Moss M.O. Food Microbiology, University of Surrey, Guild Ford, UK. RS. P. 12, 23, 122, 123, 1999 305-309.

[2] Brown G. E, A Report on the Prevalence of Bacteria specie in Retailed Smoked Fish within Bauchi Metropolis. 2004.

[3] Prescott, L.M., Harry, J.P. and Klein, D.A, Food and Industrial Microbiology. Chapter 43, $4^{\text {th }}$ Edition, New york, Mc Graw Hill publication. 1999.

[4] Adegoke G.O, Understanding Food Microbiology, $2^{\text {nd }}$ Ed 2004 p.173-174

[5] Singleton P, Bacteria in Biology, Biotechnology \& Medicine. 4 thEdition P. 324-338 John Wiley \& Sons Ltd., Chichester ISBN 0471-97468-4. 1997.

[6] Cheesbrough District Laboratory Practice in Tropical Countries Part 2. 2000 P. 13, 48-49, 62-70.

[7] Oyeleke, S B. and Manga, B. S, Essentials Of Laboratory Practicals in Microbiology 2008. P. 63-65.

[8] James, M. Modern Food Microbiology, $6^{\text {th }}$ Edition. Aspen Publication. 2000, P.152-154.

[9] Umoh, U.J. and Odoba M.B. Safety and Quality Evaluation of Street Foods Sold in Zaria kuna State, Nigeria. Nigeria Journal, 1999, 10:9-14. 